\title{
Transnational and entangled histories of National Socialism? The Turkish dimension of German interwar history
}

Stefan IHRIG

\begin{abstract}
The history of National Socialism is mostly narrated and researched within its national, German context. While it appears obvious that Germany was interconnected with the broader world at the time, this has had little impact on our understanding of the history of National Socialism. This article investigates the Turkish dimension of especially early National Socialism and shows how debates on Turkey and recent events there influenced and shaped debates in the German media in the early Weimar republic. The Turkish War of Independence (1919-1923) as well as the Armenian Genocide during World War I Turkey were topics of public debate in the early Weimar Republic. While this seems surprising, if not unlikely at first, it is through translation of these events into wholly German terms and dimensions that they became highly relevant to Germany at the time. This is a contribution to entangled history and media history as it proposes a new way to understand international history and influences through public debates, news coverage, and political discourse.
\end{abstract}

Keywords: Mustafa Kemal Atatürk, Adolf Hitler, National Socialism, Turkish Republic, Weimar Republic, entangled history, media discourses, Armenian Genocide

One of the trends of the recent years in historical research and writing has been to examine transnational and entangled histories. This approach attempts to offer new perspectives on established topics and themes. One of the core motivations behind this approach has been the dominance of the national perspective on many crucial topics, especially of $19^{\text {th }}$ and $20^{\text {th }}$ century history, to the neglect of their broader, international context. This is arguably especially true for the history of the most crucial aspects of modern history, including fascism in general and National Socialism in particular. The Nazis and, of course, Germany in the 1920s and 1930s were part of a globalized and globalizing world with increased movement of goods, ideas, and people.

This appears to be obvious. And yet, classically, the history of the rise and the origins of National Socialism is told almost exclusively in national terms - the German Empire, World War I, problems of the Weimar Republic, and the Third Reich. An obvious test case or perhaps an obvious exception is Italian Fascism how could we not expect that there was some influence exerted by it on National 
Socialism. At least with the March on Rome? The assumed role-model function of Mussolini, mainly deduced from the later significance of Fascist Italy, has led many authors to overestimate Italy and the March on Rome, and even to infer that the Hitler Putsch was explicitly intended to copy the March on Rome. And yet, many histories of National Socialism even do not really discuss the Italian case at all. Furthermore, we still know very little by way of concrete transnational influences, translations and entanglements even when it comes to early National Socialism and Italian Fascism.

There are good reasons for discussing the history of fascism primarily from a domestic point of view. In the end, the domestic arena and domestic politics are key. In the end, no entangled and transnational approach will change the key determinants and tenets of the history of National Socialism. It was a German story; guilt and responsibility belong to Germany alone. No outside connections or influence can take that away.

Two aspects of German history and historiography have surely held back new approaches of entangled history: the fear of appearing to deflect guilt away from Germany and the experience of the Historikerstreit. The latter centered around Ernst Nolte, who had worked on the international dimensions of the history of fascism. With his comments in the late 1980s he appeared to build an international causality that made National Socialism look like an automatic reaction to outside forces, such as the threat and politics of Bolshevism. ${ }^{1}$ Arguably, this and the debate that followed greatly affected the examination of National Socialism in the world in a negative fashion.

In the following a short exposé will discuss one dimension of transnationality of early National Socialism: the often forgotten Turkish "role-model." Contemporary and recent developments in Turkey in the years following World War I exerted such a force on the world at the time that also German nationalists were influenced by them. In this fashion, the following discussion highlights the "Turkish roots" of National Socialism.

\section{The Turkish War of Independence as a German media event}

Questions of international entanglement are always questions of "translation" in a way. Translation can take many forms - texts, stories, discussions, people, their correspondence, etc. Here it was mostly a case of translation by and in the media -

1 Ernst Nolte, Der Faschismus in seiner Epoche: Action française, italienischer Faschismus, Nationalsozialismus (Munich: Piper, 2000 [1963]); Ernst Nolte, Der europäische Bürgerkrieg, 1917-1945: Nationalsozialismus und Bolschewismus (Berlin: Propyläen, 1987); compare Richard J. Evans, In Hitler's Shadow: West German Historians and the Attempt to Escape from the Nazi Past (New York: Pantheon, 1989), esp. 24-46. 
though there were other venues as well. ${ }^{2}$ It was also this aspect of translation that might explain why Italian Fascism was perhaps not as immediately relevant to Germany as Turkey in these years. The situation in Germany and Italy was more different - at least according to many German contemporary commentators than that in Germany and Turkey.

In any case, one could have expected that the focus of the German postwar media would have been on Germany, and exclusively so. Germany was in revolutionary turmoil, in almost every sense of the word: loss of the World War, of the empire and the emperor, of the old political order in general, democracy had come upon Germany, there was widespread resistance, and even coup attempts. And still in these very post-war years Turkey not only became a topic, but a major one, all the way up to 1923 . The reason was simple: "Turkey" became a wholly German topic. ${ }^{3}$

This almost absolute translation rested on two basic premises. The first is an intimate familiarity - Germany and Turkey were close through many years of cooperation and especially the World War I alliance. Thus Turkey, names of people and places there, its recent history, etc. were relatively familiar to German newspaper readers. The second premise stemmed from a perceived parallel situation - Turkey, too, had lost the war and it, too, was now facing very harsh peace treaty stipulations. This alone would have made an inclusion of Turkey into general pieces on the new post-war situation "normal." And it was indeed in this fashion - plus occasional news on the fate of German military men who had served in the Ottoman Empire - that Turkey sometimes was discussed in the press immediately after the war. ${ }^{4}$ And thus, at first, in the months after the end of the war Turkey was a minor but constant topic in German newspapers.

But then, in 1919, things took a turn for the dramatic - after the Greek army had landed at Izmir, a Turkish nationalist resistance movement had formed and, a little later, Mustafa Kemal Pasha took over the leadership of that movement. It was only two days after the German press had announced to its depressed and shocked readers that the Treaty of Versailles had been signed by Germany that

2 See my discussion of the "German Ottomans" in Stefan Ihrig, Atatürk in the Nazi Imagination (Cambridge, MA: Harvard University Press, 2014), 101-104.

3 For more details on the following discussion, see Ihrig, Atatürk in the Nazi Imagination, chapters $1-3$.

4 See for example: "Das Schicksal Liman von Sanders," Kreuzzeitung, June 8, 1919; "Die äußere Politik der Woche," Kreuzzeitung, January 28, 1920; "Auslieferungsbegehren auch an die ehemaligen Bundesgenossen?," Kreuzzeitung, February 7, 1920; "Fortsetzung der Auslieferungsliste," Kreuzzeitung, February 12, 1920; “Imhoff Pascha verhaftet," Kreuzzeitung, February 21, 1920. 
Mustafa Kemal was introduced to the German newspaper reading public for the first time by name as the leader of the Turkish resistance movement. ${ }^{5}$

From that point onward and after some initial confusion the German imagination ran wild. The Turkish War of Independence became a spectacle for the German press, a true "media event." What this meant in quantitative terms can be exemplified by one paper: The Neue Preussische (Kreuz-)Zeitung, formerly a newspaper of major importance, now, in the post-war years, still influential on the German elites, published at least 194 items on Turkey in 1919; 369 in 1920; 454 in 1921; 853 in 1922; and at least another 323 up to August in 1923. ${ }^{6}$ Sometimes, of course, the items in question were short two-liners with a headline, but the overall quantity itself is a significant indicator of the value attached to the topic. In fact, items on Turkey often dominated the first page, and often these articles consisted of an entire column or even half a page. At least 2,200 articles, items, and reports in the Kreuzzeitung in a period of only about four and a half years is by itself an extraordinary amount. On average this meant at least one article per day or three articles per two days. While there were sometimes days without articles on Turkey, rarely was there a week without Turkey. Often there were many successive days when half of the first page was devoted to Turkey, with additional items in the section "Latest News" on page 3 or 4 . Regularly, Turkey featured in both the morning and the evening edition. There has never been another period with such an amount of articles in the German press devoted to Turkey, not even during the high points of the recent EU-Turkey debate (in the early 2000s). Coverage in the German press was so extensive in the post-war years that in early 1923 a commentary in the Deutsche Allgemeine Zeitung claimed that in the summer of 1922 one had been able to read about Turkey "daily, a thousandfold" in the German papers.

But of course it was not only the large amount and the continuous character of coverage that mattered; it was how Turkey and Mustafa Kemal were covered and translated. To say that this was an example of "positive coverage" would be a gross understatement. What was happening in Anatolia in the post-war months and years was like a nationalist dream come true for desperate and depressed German nationalists. And it was playing out right in front of them and on a daily

5 See for example: "Aufstandsbewegung in Anatolien," Kreuzzeitung, July 1, 1919; "Aufstand in Anatolien," Vossische Zeitung, July 1, 1919.

6 For a discussion focused exclusively on the Kreuzzeitung and the Turkish War of Independence see: Stefan Ihrig, "'Why them and not us?' - The Kreuzzeitung, the German Far Right, and the Turkish War of Independence, 1919-1923," in Beyond the Balkans - Towards an Inclusive History of Southeastern Europe, ed. Sabine Rutar (Zürich: Lit Verlag, 2014), 377-404.

7 “Levante und deutsche Not," Deutsche Allgemeine Zeitung, February 10, 1923. 
basis in the German press while Germany was living through its darkest hours (at least in the nationalist imagination and at least to date). It was truly incredible to see how the former ally - often in the past perceived rather as a liability - was able after almost ten years of continuous warfare to continue fighting, to even think about taking on all the Entente allies plus their proxy, the invading Greek army.

And from there it became even more incredible: the Turkish nationalists even seemed to be winning. Long before anything was for sure, the German nationalist papers became convinced that there was basically nothing the Entente could do (given the geography and their own war exhaustion). ${ }^{8}$ Discussing Turkey in these years also meant unleashing an incredible amount of Schadenfreude leveled at the Entente. It meant, for German nationalists, exposing the weaknesses and divisions among the Entente as well as showing that the Entente was merely about conquest and profiteering."

Mustafa Kemal became a shining star, a light in the darkness for German nationalists - as these words taken from the mouth of Adolf Hitler (in 1933) about the Turkish role-model show. But it went far beyond a radical far-right fringe. Now, articles appeared, inciting cross-paper debates on the Turkish rolemodel and on how to best translate and apply "Turkish lessons" to Germany. Debates about Turkey and Mustafa Kemal were immediately connected to the revolutions in state systems that had occurred, i.e. the end of the monarchical rule in Germany and in other states. The nationalist press often focused on the metaphysical question about whether it was (single) men or the masses, i.e. monarchs or autocrats or democracy, who "made" history, who led the nation to greatness.

One of these centered around the question about a "Mustafa on the River Rhine?," i.e. a German leader who would take Mustafa Kemal's role for Germany and "liberate" it. ${ }^{10}$ There were, of course, also voices opposing these translations of the Turkish case, famously so Carl von Ossietzky in June 1921. ${ }^{11}$ His article was interesting for two aspects: First for his principled rejection of any Turkish lessons and secondly, for the fact that it appeared the same day as another article propagating Turkish lessons penned by Friedrich Hussong, a man later described as Goebbels' teacher. Ossietzky's was a lone voice in a sea of nationalist euphoria.

8 Cf. "Die äußere Politik der Woche," Kreuzzeitung, December 15, 1920; “Die Lage der Entente im Orient," Frankfurter Zeitung, November 12, 1922.

9 Cf. my debate in Ihrig, Atatürk in the Nazi Imagination, 33-43.

${ }^{10}$ A critical response: "Mustapha am Rhein?, Vorwärts, March 28, 1922.

${ }^{11}$ Carl von Ossietzky, “Der Fall Angora," Berliner Volks-Zeitung, June 19, 1921. 
Hussong's article is an exemplary expression of this euphoria. Hussong was a fierce antidemocratic, revisionist, and anti-Semitic polemicist. He is often viewed as one of Goebbels's major teachers. Hussong regularly wrote for the Berliner Lokal-Anzeiger, openly sympathized with Hitler during the putsch of 1923, and is credited with winning over many readers as voters for Hitler later. In his essay "Man and Masses", Hussong depicted Germany as a castrated nation which was caught up in a "delirium of the masses," by which he meant democracy. ${ }^{12}$ Yet there was, Hussong juxtaposed, one remarkable example of a way out: the creative "Führer personality" of Mustafa Kemal, a man who transformed a disoriented and helpless mass into a nation and into an army; a man who was giving the masses a purpose: "The man Mustafa Kemal rises and turns a seemingly helpless and unstable, disoriented and faltering mass into a unified nation; a will rises and creates ascent from doom; a Führer rises and shows the way ... where once one saw only abyss and doom."

For Hussong, Atatürk was a "man of steel," a man "charged like an accumulator" with a will like "pressed steel," able to do just about anything. In his essay, Hussong re-narrated Atatürk's biography and his success story in order to "disprove" German democracy, if not democracy as such, and to tell Germany what it needed. He recounted recent Turkish history in epic style, stressed the "will of the man" who was able to break the "chains of servitude" of the Treaty of Sèvres, and listed all the signatories of that treaty in order to show just how impossible Atatürk's endeavor must have once appeared. Regardless of how Atatürk "completed his fate" in the future, Hussong stressed that his role was transcending all this: "we owe him the rehabilitation of the honor of the man against the idolaters of the masses." With this Hussong closed his call for a Führer.

There are many more examples of how the Turkish War of Independence and Mustafa Kemal's role were part of broader debates about the future of nations and mankind: After extensive reporting on Turkey, the Kreuzzeitung, for example, exclaimed: “Men make history!” In the Deutsche Allgemeine Zeitung, Thea von Puttkammer summarized her article on Atatürk, among other things, with the following Turkish lessons: "In Germany, where the heroic is worth disgracefully little [nowadays], much more attention should be paid to how much the will of a single man can accomplish." 13

These are just a few examples of how the Turkish model radiated into Germany, how it was "translated" and how it was felt that it was relevant to

${ }^{12}$ Friedrich Hussong, “Mann und Masse," Berliner Lokal-Anzeiger, October 1, 1922.

${ }^{13}$ Thea von Puttkammer, "Begegnungen mit Mustafa Kemal," Deutsche Allgemeine Zeitung, September 27, 1922. 
Germany. It needs to be remembered that it was in these years, and thus in this atmosphere that the Nazi party and the National Socialist movement were founded. Unsurprisingly, the Nazis, too, were enthralled by the Turkish role-model. Right after the Völkischer Beobachter - the paper that became the mouthpiece of Nazis and later the flagship of the Third Reich press - was acquired by the Nazi party (in late 1920), the paper featured, on January 1, 1921, the telling headline "Heroic Turkey." ${ }^{14}$ Barely a month later the paper printed an article with the headline "Turkey — The Role Model" (or "The Pioneer")..$^{15}$ The Völkischer Beobachter exclaimed: "Today the Turks are the most youthful nation. The German nation will one day have no other choice but to resort to Turkish methods as well." With such an explicit call to apply "Turkish methods" already in early 1921, the Völkischer Beobachter was in fact well ahead of most of the German papers. Within a month it reiterated that at some point Germany would "not be spared" the "practical application" of the Turkish case. ${ }^{16}$

However, after April 1921 the paper refocused almost exclusively on Germany and its core issues to the neglect of all foreign developments. Now it was up to another Nazi paper, the Heimatland, to carry the torch. ${ }^{17}$ The Völkischer Beobachter offered daily commentary, mostly on Jewish and Bolshevik topics, while the Heimatland offered long-form essayistic discussion of a variety of contemporary political issues.

Various Heimatland articles discussed the Turkish model in the coming months, the first high point of this debate being a two-part article "National SelfHelp of the 'Sick Man." 18 But the main exposé was a six-part series on "Mustafa Kemal and His Achievements" written by Hans Tröbst, who had served with the Kemalists during the War of Independence. He had been the only foreigner to do so. The series in the Heimatland was Tröbst's first step on his future career path as a journalist. It had been German "war hero" and now focal point of the revisionist far right, Erich Ludendorff who had motivated Tröbst to write about Ankara and the Kemalists for the Nazi weekly. ${ }^{19}$

This was the largest feature series in the history of the Heimatland as well as probably the largest feature on Turkey in the whole of interwar Germany. The

14 “Außenpolitische Rundschau: Die heldenhafte Türkei,” Völkischer Beobachter, January 1, 1921.

15 "Die Türkei: Der Vorkämpfer," Völkischer Beobachter, February 6, 1921.

16 "Die Entente und die Türkei," Völkischer Beobachter, March 10, 1921.

${ }^{17}$ For a more detailed discussion of the Heimatland and Turkey see Ihrig, Atatürk in the Nazi Imagination, 71-101.

18 “Die nationale Selbsthilfe des 'kranken Mannes,” Heimatland, pt.1, June 18, 1921; pt. 2, June 25, 1921.

${ }^{19}$ Gebhardt Hartwig, Mir fehlt eben ein anständiger Beruf: Leben und Arbeit des Auslandskorrespondenten Hans Tröbst, 1891-1939 (Bremen: Edition Lumière, 2007), 20, 23. 
editors of the Heimatland were quite enthusiastic and jubilant about this series. Their introduction underlined this: "The fate of Turkey shows extraordinarily many similarities to our own; through Turkey we can learn how we should have done it. If we want to be free, then we will have no choice but to follow the Turkish example in one way or another." ${ }^{20}$ Thus they made clear at the outset that there was a certain timelessness to the Turkish role model.

The way the author himself introduced his series also captured its spirit and content:

The political situation of Turkey after the signing of the Treaty of Sèvres is well known. It is the same as our Fatherland is in today, four years after the [signing of the] Treaty of Versailles. The Empire sunk down to be a colony of the Entente, vital provinces severed by the stroke of the pen, the enemy inside the country, imminent anarchy and civil war, and the nation without defense and honor...

In the six extensive articles Tröbst discussed the whole of the War of Independence focusing especially on tactics and logistics. He repeatedly condensed the lessons for Germany into three compact points: an army of volunteers, the nation united under a strong leader figure, and the "purification" of the nation from its minorities (more on that point below).

The conclusion read:

A united front, national purification and a true army of volunteers, these are today the essentials for a national rebirth of a nation.

This is, in a few words, the great lesson we can take away from the Turkish struggle for freedom.

When will the savior of our country come, he who will fulfill the demands of the hour? ... ${ }^{21}$

A week later, the paper featured more discussion of the Turkish role-model in various articles. Two weeks after the six-part series had been concluded, the dominating title page headline read "Give Us an Ankara government!"22 The Heimatland claimed that the time was ripe and that German nationalists should rise up and make Munich the new, alternative capital of Germany - like Mustafa Kemal had made Ankara the second capital of Turkey (against the corrupt and powerless Constantinople). From Munich then, like for Turkey from Ankara, Germany would be liberated. The next issue of the Heimatland again discussed

\footnotetext{
${ }^{20}$ Hauptmann Tröbst, "Mustafa Kemal Pascha und sein Werk (I)," Heimatland, September 1, 1923.

${ }^{21}$ Hauptmann Tröbst, "Mustafa Kemal Pascha und sein Werk (VI)," Heimatland, October 15, 1923.

22 “Her die Angora-Regierung!," Heimatland, October 27, 1923.
} 
the Turkish role-model. ${ }^{23}$ And only five days after this issue of the Heimatland Hitler decided that the time was right for his coup d'état in Munich, underlining the fact that the so-called Beer Cellar Putsch of 1923 was much more inspired by the Turkish model than by Mussolini's March on Rome.

This was also underlined by various statements made at the 1924 trial following the failed coup attempt. Hitler himself quoted Mustafa Kemal as a role-model in his defense speech in front of the court. ${ }^{24}$ After the Hitler Trial things quieted down around the Turkish example. To talk about Turkey now became a dangerous thing. But when Hitler was about to be indicted for treason once more, later in the 1920s, he again referred to the example of Ataturk as his vindication in the defense statement he prepared. ${ }^{25}$

It was only after the Nazis seized power that it was safe again to refer to the Turkish role-model. But they did much more. Starting in 1933, a minor cult around Atatürk and the New Turkey began in the Third Reich. While it found few direct applications, it was an important part of the overall discourses of Führer, national revival, and of revisionism. ${ }^{26}$

Right at the beginning of the "Third Reich," in early 1933, Hitler said in an interview that Atatürk had been his shining star in the darkness of the 1920s. This then became the official line of the Third Reich on Turkey. ${ }^{27}$ There are many more such quotes from Hitler. But what is important is that the Third Reich press continued the early 1920s adulation of the Kemalists. It was a mix of genuine respect and admiration on the one side coupled with self-serving propaganda goals on the other: The New Turkey was used as a role-model to put forward an exposition of what the Nazis deemed the perfect state: Führer-centered, reinventing itself, re-construction of a völkisch society, energetic, uncompromising, etc. But it was a distorted image of the New Turkey, of course. Certain aspects of modern Turkey that did not fit the Nazi worldview were largely ignored or played down: the language reforms, the emancipation of women, and Ataturk's peace-oriented foreign policy. Other topics, such as the radical secularization of Turkish society were important for the Nazis, but only behind closed doors. These were still too radical to be championed in public. Yet, they provide hints

${ }^{23}$ For example: "Berliner Brief," Heimatland, November 3, 1923.

${ }^{24}$ See especially: Lothar Gruchmann et al., eds., Der Hitler-Prozess 1924, vol.4: 19-25 Verhandlungstag (Munich: K.G. Saur, 1997), 1574-1575.

25 "Stellungnahme zu einem Ermittlungsverfahren wegen Hochverrats," doc. no. 7, in Institut für Zeitgeschichte, ed., Hitler: Reden, Schriften, Anordnungen, Februar 1925 bis Januar 1933, vol. 2, pt. 2 (Munich: K.G. Saur, 1992), 72-100, here 83.

${ }^{26}$ See Ihrig, Atatürk in the Nazi Imagination, chapters 4 and 5.

27 See my discussion: Ihrig, Atatürk in the Nazi Imagination, 114-143. 
as to where some top-level Nazis, most prominently Hitler himself, saw German society to be heading even if this was too radical to be publicly acknowledged yet.

\section{The great German genocide debate}

Similarly radical, yet alluded to before 1933 were the proposed or imagined "solutions" to the minority question, i.e. so-called Jewish Question. Indeed, this was a key component of the Nazi and Third Reich vision of the new völkisch (i.e. ethnic/national) state and it was put forward in their discussions of the New Turkey, in the early 1920s, as well as in the Third Reich. The question about the role of ethnic minorities in national history and what was to be done with them was discussed through the Turkish example and the cases of the Armenians and Greeks.

This was also connected back to the early 1920s, to yet another debate around Turkey that had played out in the German press in parallel to the media hype around the Turkish War of Independence. But both discussions were almost entirely parallel and disconnected. They were only brought together briefly in 1923 when the discussions around the Treaty of Lausanne, ending the Turkish War of Independence, led to grand total conclusions. This second ethnic, or "Armenian," dimension focused on the recent past and not on contemporary developments in Turkey, at least not explicitly. During World War I, often quite neglected in history writing today, more than a million Armenians of the Ottoman Empire perished in the Armenian Genocide. At the time and in the immediate aftermath, this was well known to the key international players. It was also known to the German leadership. ${ }^{28}$ But it had not been a major topic of public debate during the war as arguably it had been in the Entente countries where it had been part and parcel of World War I atrocity propaganda. The war effort and censorship heavily clouded the topic. There had been instances, especially in 1915 in which Germany had interacted with Entente atrocity allegations to such an extent that many details had actually found their way into the German press. ${ }^{29}$ But there had been no full debate on the Armenian topic, let alone on the Armenian Genocide in its truly genocidal dimensions (which, as the following shows, was possible even before the term "genocide" was coined).

${ }^{28}$ Stefan Ihrig, Justifying Genocide: Germany and the Armenians, from Bismarck to Hitler (Cambridge, MA: Harvard University Press, 2016); see also the articles in the recently published documentation: Yetvart Ficiciyan, ed., Der Völkermord an den Armeniern im Spiegel der deutschsprachigen Tagespresse (1912-1922) (Bremen: Donat Verlag, 2015).

${ }^{29}$ See for reactions to specific allegations in 1915: Stefan Ihrig: "Lord Bryce and the Armenian Genocide in German Wartime Propaganda," Journal of Levantine Studies 2 (2015): 51-70. 
Despite censorship and propaganda, German newspaper readers would have been aware that something had happened to the Ottoman Armenians that went far beyond pogroms and deportations. German and Ottoman propaganda had simply protested too much. Part of the protestations had been the German and Ottoman propaganda claim that all the Armenians had risen up against the Ottoman state, while the Ottoman armies were fighting for the survival of the Ottoman Empire - as already in 1915 press propaganda it had been a devious Anatolian stab in the back executed by all Armenians, still years before the German version of the stab-in-the-back myth had yet been invented.

After the war, just as much as this applied to the Turkish War of Independence, it seemed at first, there was too much going on in Germany for there to be much further debate. But the opposite occurred: a great German genocide debate from 1919-1923. ${ }^{30}$ Very similar to how the Turkish War of Independence had entered the German press and thus public discourse, the Armenian topic too only entered the German press through entirely "German" vintage points. Translation, again, depended on the domestic language, discourse, and, in general, interest.

While German pro-Armenian activists had tried to create awareness for what had happened during World War I to the Ottoman Armenians in various articles published in the weeks and months after the end of the war, it was only an intervention, with unintended results, by the German Foreign Office that brought the topic to the fore - and with a vengeance. ${ }^{31}$ The reason is simple and again very German: Already in the midst of the Armenian Genocide the German Foreign Office became anxious that what was happening to the Armenians would be used against Germany after the war. ${ }^{32}$ In 1919, while the world was in session in Paris to decide upon the fate of the losers of World War I, this anxiety heightened to such an extent that the Foreign Office decided to ask Johannes Lepsius - the world's foremost pro-Armenian activist, since the 1890 s already - to edit a volume of documents from its diplomatic correspondence on the Armenian topic. The idea was to show that Germany was innocent of having initialized the genocide or having colluded with the Ottomans. To the contrary, the German Foreign Office wanted to show that it had done everything to stop

${ }^{30}$ Ihrig, Justifying Genocide, chapters 9-12.

${ }^{31}$ See some examples of (early) articles by pro-Armenian activists: Johannes Lepsius, "Was hat man den Armeniern getan? Die Zeit zu reden ist gekommen," in Aus der Arbeit von Dr. Johannes Lepsius 11/12, September/December 1918, 113-118; here: 116; Ewald Stier, "Armenien," Frankfurter Zeitung, January 21, 1919; Julius Richter, "Die deutschen evangelischen Missionskreise und das armenische Volk," Allgemeine Missionszeitschrift, February 6, 1919; Armin T. Wegner, "Armenien - Offener Brief an den Präsidenten der Vereinigten Staaten," Berliner Tageblatt, February 23, 1919.

32 See Ihrig, Justifying Genocide, 129-134. 
the genocide in progress and to help the Armenians. This was stretching the truth a bit far and it is difficult not to agree with the assessment of the New York Tribune of the volume and Germany's role:

What did Germany do to save the Armenian people from extinction? ... In other words, Germany said naughty, naughty, Turkey did not care, and Germany shrugged her shoulders. This is what the "complete vindication" actually amounts to. It leaves the matter standing just where it stood before. ${ }^{33}$

Thus, abroad, the endeavor of the Foreign Office hardly succeeded. Yet at home it largely did. German papers had eagerly discussed the volume, which was rushed to publication and was on the market already in the summer of 1919, and just as eagerly they had accepted that Germany was innocent. ${ }^{34}$ But the publication also initiated a debate about the Armenian Genocide itself. Lead articles in many papers spoke about the "murder of a nation," described in detail what had happened, and argued that now a period of disclosure and coming to terms with a barbarous war would begin.

One of the key commentaries on the Foreign Office documents was penned by Theodor Wolff, one of the most important newspaper men of the time, on the title page of the Berliner Tageblatt. ${ }^{35}$ This commentary was one of the most extensive and earliest ones. It set the tone for the reception of the documents in Germany and abroad. ${ }^{36}$ Reading the documents of the Lepsius volume, one would feel the urge to "plead to the cruel god, three times," Wolff wrote and stressed that "there is a measure of misery and nefariousness that makes big words small [...] There is that kind of horror that cannot stand pathos." He detailed the whole genocidal undertaking beginning with the arrest and eventual murder of the Armenian intelligentsia in Istanbul "so that every loud cry of protest was made impossible." He directly addressed authorship and strategy: "After the Enver gang gained through these provoked conflicts the pretext for the purported military necessity of 'security measures," the "deportation" began, the butchering began: "the strangling angel [of death] pushed the unlucky nation from all sides, under beastly conceived agonies, into their grave." Wolff recounted how everybody,

33 "Germany and the Armenians," New York Tribune, August 14, 1919, in Armenocide - Documents from the State Archives, ed. Wolfgang Gust, online at www .armenocide.net.

${ }^{34}$ Johannes Lepsius, Deutschland und Armenien, 1914-1918: Sammlung diplomatischer Aktenstücke (Potsdam: Tempel-Verlag, 1919).

35 Theodor Wolff, Untitled commentary, 1-2, Berliner Tageblatt, July 28, 1919.

${ }^{36}$ Cf. "Ein Dokument jungtürkischer Schande," Braunschweiger Landeszeitung, July 29, 1919; “Die Ausrottung der türkischen Armenier," Vossische Zeitung, July 30, 1919; "Der Massenmord am Armeniervolk," Kölnische Volkszeitung, August 2, 1919; for more examples from these weeks and months: Yetvart Ficiciyan, ed., Der Völkermord an den Armeniern im Spiegel der deutschsprachigen Tagespresse (1912-1922) (Bremen: Donat Verlag, 2015), 302-318. 
"men, women, children," had been beaten to the edge of the desert to the "concentration camps." He then related how the men had been murdered first and how some of the women and girls had been sold into harems "and Kurdish villages." After further details of the horrors Wolff concluded: "If you want more of the sort, the five-hundred pages [of the Lepsius volume] are filled with such occurrences. On Turkish soil, according to the existing estimates, approximately one million humans were thus, in unspeakable atrociousness, annihilated and in addition [a] hundred thousand in the Caucasus."

The Wolff essay illustrates both the depth of information and discussion as well as the moral outrage following the German Foreign Office publication. Many similar articles appeared in the following days, weeks, and even months later. One, for example, in the Vossische Zeitung, was titled "The Extermination of the Turkish Armenians." ${ }^{37}$ Many of these commentaries followed Wolff's example in sentiment and in putting forward a lengthy exposé of what had happened based on the Foreign Office documents.

It could have ended there, but it did not. After a wave of outrage and condemnation followed a long denialist year in which German nationalist papers reacted against this new apparent consensus (from the end of 1919 until early 1921). In this long year (almost one and a half) a stream of articles and commentaries was published that denied the extent of what had happened and put forward full justifications for the extent of the violence that even they acknowledged..$^{38}$

Again, it could have ended here, but it did not. It is important here to remember that unlike the coverage of the Turkish War of Independence this was a debate about a past event. There were not many external stimuli for German society to discuss it or to come back to it - the Paris peace treaty negotiations and the Foreign Office publication had been such stimuli. But what about the period after 1919? These stimuli were the shots fired in March 1921 in Berlin by the Armenian Soghomon Tehlirian in a crowded Berlin street. They killed Talât Pasha, former Grand Vizier and Minister of the Interior, often seen as the key instigator and executor of the Armenian Genocide. This assassination revived the debate on the Armenian topic, but at first only in a hesitant fashion. ${ }^{39}$ It was the spectacular trial of Tehlirian in Berlin in the summer of 1921 that brought the debate to new heights and then to a disturbing reaction and to even more disturbing conclusions. ${ }^{40}$

\footnotetext{
37 “Die Ausrottung der türkischen Armenier," Vossische Zeitung, July 30, 1919.

${ }^{38}$ For more on this see: Ihrig, Justifying Genocide, 219-225.

${ }^{39}$ See Ihrig, Justifying Genocide, 227-233.

${ }^{40}$ Stefan Ihrig, "Justifying Genocide in Weimar Germany - The Armenian Genocide, German
} 
This trial itself became one of the most spectacular trials of the $20^{\text {th }}$ century with a multiple reversal of roles: In the end, it was rather Talât Pasha and by extension the Ottoman Empire that were on trial rather than the assassin himself. This was possible because of another reversal of roles that saw the judge and at times even the state prosecutor acting as if they were part of Tehlirian's defence team. And then Tehlirian was acquitted which provoked further and far-reaching discussions of the genocide for months to come.

The trial had begun with Tehlirian's (alleged) story of survival, involving him lying unconscious under the corpse of his brother who had been killed in a massacre, his head having been split in two by an axe. Besides the murder of Tehlirian's parents and relatives in this massacre, his story also recounted other aspects of the brutal history of the Armenian Question. The claim to "genocide" was most clearly established by the "expert witness" and key witness for the defense: Johannes Lepsius. His testimony was reprinted, mainly in direct speech, in most papers. ${ }^{41} \mathrm{He}$ cited a telegram by Talât Pasha that "the destination of the deportations" was "nothingness' and that with a few exceptions all Armenians of Anatolia had been deported. "When the concentration camps were overfilled $[. .$.$] the people were led into the desert and butchered." Lepsius concluded: "It$ was not a resettlement but the open intention to destroy an entire people. Only with the most brutal methods could one million people have been destroyed in such a short time." Similarly, the Armenian bishop of Manchester, who had been living in Berlin before the war and had been among the Armenian community leaders deported from Constantinople on 21 April 1921, told many shocking stories of genocide to the Berlin court.

The trial radically changed the outlook of the whole German mediascape on the genocide. Now, it was no longer only the Left plus some other papers who were acknowledging the full extent of genocide. Now, the rest of the papers had also little choice but to recognize it; a critical mass of recognition had been reached. Across the board in these weeks of June 1921 "genocide" in various contemporary terms such as "murder of a people," "extermination" or "annihilation of the Armenians" - established itself as fact, with an

Nationalists, and Assassinated Young Turks in Berlin, 1919-1923," in Re-writing German History: New Perspectives on Modern Germany, ed. Jan Rüger and Nikolaus Wachsmann (London: Palgrave Macmillan, 2015), 215-232.

${ }^{41}$ For example: "Die Ermordung Talaat Paschas vor Gericht - Die Vernehmung des Angeklagten," Berliner Börsenzeitung, June 3, 1921; "Das Attentat auf Talaat Pascha - Der Armenier Teilirian vor den Geschworenen," Berliner Morgenpost, June 3, 1921; “Die Ermordung Talaat Paschas Berichte der Zeugen über die Armenier-Greuel," Berliner Lokal-Anzeiger, June 3, 1921; “Der Mörder Talaat Paschas vor Gericht - Die armenischen Greuel," Germania, June 3, 1921; "Die Ermordung Talaat Paschas," Deutsche Zeitung, June 3, 1921. 
acknowledgment and discussion of the full intent, extent, and the politics behind it. Before the so-called "Talât Pasha Trial," the papers, the public, and German politicians had been split between those acknowledging "genocide" in wartime Anatolia and those denying it as well as the alleged extent of such atrocities and any intent behind it. For the first two years this opposition between "accepters" and "deniers" had been rock-solid. Only a few papers in the middle had been oscillating between pro- and anti-Armenian positions. The denialists were rooted deep in the German history of pro-Ottoman politics and worldviews which up until then had included an anti-Armenian outlook. For two years, but especially so during the year before Talât Pasha's assassination they had bombarded the German public with anti-Armenian articles and essays claiming that whatever had happened had been the Armenians' own fault as they had committed "wartime treason" and had stabbed the Turks in the back. Their deportation had been of utmost "military necessity" and any casualties - and the denialist papers, until 1921, had denied a high death toll - were by-products of war; "collateral damage" in today's language. ${ }^{42}$

But in the summer of 1921, there was, apparently, no longer any scope to deny genocide. The critical mass created by the Talât Pasha Trial pushed all the German media outlets over the edge, resulting in all of them acknowledging genocide. This now included the former denialist papers as well, who, however, continued to justify ever more aggressively what had happened in Anatolia. Before, justifications had already been part and parcel of their discourse, but its main aim had been to deny that anything of note had happened in Anatolia during the war. But now, their continued justification was, in fact, defending and excusing genocide.

After this tectonic shift, such arguments were repeated in a veritable media offensive by the "justificationalist" papers; the "avant-garde" was led by Hans Humann's Deutsche Allgemeine Zeitung, followed closely by such papers as the Deutsche Zeitung and the Deutsche Tageszeitung. ${ }^{43}$ The Frankfurter Allgemeine Zeitung, already in an essay on 7 June, had also squared the genocidal circle by at once acknowledging the "Barbarian extermination" of the Armenian people and at the same time stressing that the Armenians were not of "angel-

${ }^{42}$ On the German discourse concerning "military necessity" cf. Isabel V. Hull, Absolute Destruction: Military Culture and the Practices of War in Imperial Germany (Ithaca/London: Cornell University Press, 2005).

${ }^{43}$ For example: "Der Freispruch des Mörders," Deutsche Allgemeine Zeitung, June 4, 1921; "Der Freispruch,” Deutsche Zeitung, June 4, 1921; “Zum Freispruch des Mörders Talaat Paschas," Deutsche Tageszeitung, June 4, 1921. 
pure innocence" and had provoked the Turks to do what they had done. ${ }^{44}$ Many other papers of the nationalist fold, such as the Berliner Lokal-Anzeiger and the Kreuzzeitung, followed suit that June, as well as in the coming weeks and months. Former "German Ottomans" such as Otto von Feldmann and Bronsart von Schellendorf wrote essays for the Deutsche Allgemeine Zeitung and stressed that what had happened had been a "wartime necessity," caused by the behavior of the Armenians themselves. ${ }^{45}$ The Deutsche Zeitung, in its mid-September article "A Word for Turkey," for example, stressed again that the Armenians had been a fifth column and that they had stabbed the Turks in the back while they were fighting for their lives during the war. Again, as in other papers, and as before, the Armenians had brought upon themselves what had happened and the paper made it appear, in an abstract fashion, as if in such a context there was just little else to do, other than genocide. ${ }^{46}$

This was the mood in the nationalist papers when, in early 1922, more shots were fired in Berlin and two Young Turk functionaries were killed, again by Armenians. In an exemplary fashion let us take the hyper-nationalist Deutsche Zeitung which took the assassination as an opportunity to tackle the "foreigner question" in relation to the Armenians, Berlin, the "West," and "the Jews." The theme was the parable of the sick national body and the assertion that every doctor had to identify the illness in order to find a cure. The Deutsche Zeitung identified the disease as "the Jews." It then asked who benefitted from the disunity of Germany? Its answer was the cryptic "Berlin West," which was synonymous with "the Eastern Jews," Armenians, and other allegedly criminal foreigners. The final conclusions of the Deutsche Zeitung are illustrative of the mood in the nationalist media of the time:

Just now we have read how certain newspapers justify the murder of German-friendly Turks in Berlin, solely because the cowardly criminals were Semitic cousins. The papers show the same demeanor in all matters concerning Jewish issues and in the end the destruction of all things the Germans venerate serves the same purpose [...] The German sickness can be neither cured with constitutional cures or socialization pills, but solely and exclusively with the sharp knife of the völkisch surgeon.

The putrefaction-spreading pathogen has to be removed!

Otherwise Germany will die of the un-German essence. ${ }^{47}$

44 “Teilirian," Frankfurter Zeitung, June 7, 1921.

45 Otto von Feldmann, “Zum Talaatprozeß," Deutsche Allgemeine Zeitung, June 30, 1921; also published in the Weser Zeitung on July 4, 1921; Bronsart von Schellendorff, "Ein Zeugnis für Talaat," Deutsche Allgemeine Zeitung, July 24, 1921.

46 “Ein Wort für die Türkei," Deutsche Zeitung, September 15, 1921.

47 “Politik der Woche," Deutsche Zeitung, April 22, 1922. 
Similar articles were published across the nationalist press spectrum in these days. When a year later the Treaty of Lausanne was discussed, the Armenians were only mentioned in passing, yet often in an appreciative fashion as nationalist papers alleged that Turkey had solved its minority question in an exemplary fashion: the annihilation of the Armenians and the expulsion of the Greeks.

This debate, only superficially sketched here, revealed to the contemporary observers, like Hitler and his future co-conspirators, that there was a vocal nationalist portion of post-war Germany which apparently could see genocide as "justifiable" and part of which had advanced a plethora of excuses and even full-blown justifications for genocide, right in the centre of the public sphere, openly, and for years. The Nazis and Hitler as well as a large part of nationalist Germany lived through an almost five year-long media discussion of the Armenian Question and the Armenian Genocide. It was a large debate, with long front-page essays, with cross-paper discussions, and long op-eds of which only a handful were mentioned here. It was not merely a question of reprinting news agencies' reports or copying from the others; it appears that this was a topic about which everybody had a strong and "informed" opinion. "Genocide" was discussed in the framework of "military necessities" and justified on racial grounds. This and the confluence of "Armenians" and "the Jews" in the German public discourse - the parallel of German Anti-Armenians and Anti-Semitism going back to the 1890 s - was not lost on Hitler who repeatedly referred to the Armenians in the 1920s in a similar fashion. Neither was the highpoint of this genocide debate - the Talât Pasha Trial - ignored by the Nazis: Hitler's friend and political advisor at the time, Max Erwin von Scheubner-Richter, a former vice-consul in Eastern Anatolia, had been in the courtroom as a witness for the defense. Alfred Rosenberg still commented in 1928 on the Talât Pasha Trial in an article. ${ }^{48}$

\section{Distant but close? Media translation in the $20^{\text {th }}$ century}

None of the above described influences and "translations" change the core history of National Socialism. Yet these Turkish (and Armenian) flashlights illustrate that for some of Nazism's developments one should also have Turkey,

${ }^{48}$ Alfred Rosenberg, "Mörder und Mörderschutz," in Der Weltkampf, July 1926; for Hitler see for example: "Rede auf Generalmitgliederversammlung der NSDAP/NSDAV e.V. in München," Document no. 159 (30 July 1927), in Institut für Zeitgeschichte, ed., Hitler: Reden, Schriften, Anordnungen, Februar 1925 bis Januar 1933 (vol. 2, part 2, München: K.G. Saur, 1992), 429; "Rede auf NSDAP-Versammlung in Nürnberg," Document no. 61 (3 December 1928), in Institut für Zeitgeschichte, ed., Hitler: Reden, Schriften, Anordnungen, Februar 1925 bis Januar 1933 (vol. 2, part 1, München: K.G. Saur, 1992), 297-316, here: 310. 
contemporary developments there and the debates about it in mind. For example, the mentioned debate about "men and masses" shows that when Hitler was thinking about his role in the movement, there was the contemporary example of Mustafa Kemal and the debate it engendered in the German press in these very years.

Similarly, it is often alleged that the genocide of German and European Jews was not conceivable before the late 1930s. But the experience of the Armenian Genocide debate of the early 1920s suggests otherwise. At the very least "genocide" entered the realm of discourse and political thinking. And, at the very least, there were political forces that portrayed genocide of a group understood through contemporary racial Anti-Semitism (in its Anti-Armenian carbon copy) as "justifiable."

There were many aspects that radiated from the developments in Turkey into the world. But, in any case, one thing should have become obvious: Turkey was part of the core debates at the time. It was neither distant nor peripheral, but at the center of Germany's attention. And all this even though there were no direct bi-lateral relations. Moreover, there was no obvious German-Turkish common topic of discussion during these years (apart, perhaps, from the former Grand Vizier having been killed in Berlin). These were times in which new styles of politics were all the rage and needed to be understood, "translated", apprehended or rejected. Kemalism was one, Bolshevism another, fascism and nascent National Socialism yet another, all this in the turmoil and transition from old regimes - empire and monarchical systems - towards something new. ${ }^{49}$

The two examples - the Turkish War of Independence as a media event in early Weimar Germany and the German genocide debate around the Armenian case - should make us rethink how we approach international history. A look at the archives of the German and Turkish Foreign Offices at the time would not have betrayed what we discussed here; in fact, one would have had little indication that there had been debates and awareness at all. One reason for this was the fact that the two countries did not even have official relations in these years (it was forbidden by the armistice and peace treaties) and, of course, the Kemalists had other things to worry about than their image in Germany.

Secondly, while there existed, undoubtedly, personal connections, they were not as important as one might think or would have expected. It was precisely the fact that Turkish topics became German topics and then were covered by inhouse writers, and not by Orientalist "specialists", that enabled these questions to become such major issues at the time. Translation of world events - distant

${ }^{49}$ Compare the Italian perspective and debates: Giacomo E. Carretto, "Polemiche fra kemalismo, fascismo, comunismo negli anni ’30,” Storia contemporanea 3 (1977): 489-530. 
and close - in the domestic media should be a core component of historical enquiry. It has much to offer by way of getting a sense of any national political mood in the past, especially so in the turbulent $20^{\text {th }}$ century.

\section{Rezumat}

Cuvinte-cheie: Mustafa Kemal Atatürk, Adolf Hitler, național-socialism, Republica Turcă, Republica de la Weimar, istorie încrucișată, discursuri mass-media, genocidul armean

Istoria național-socialismului este povestită și cercetată, în majoritatea cazurilor, în cadrul contextului său național, german. Chiar dacă este o evidență faptul, că Germania a fost strâns legată de procesele care se desfășurau la nivel mondial, în acea perioadă, acest lucru nu a avut un impact semnificativ asupra înțelegerii pe care o avem în privința istoriei național-socialismului. Acest articol examinează dimensiunea turcă a perioadei timpurii de evoluție a național-socialismului. Articolul arată, cum au influențat discuțiile în privința Turciei și a evenimentelor care aveau loc acolo dezbaterile din presa germană în primii ani ai Republicii de la Weimar. Războiul Turc de Independență (1919-1923), ca și genocidul armean care a avut loc pe teritoriul Turciei în perioada Primului Război Mondial, erau subiecte de interes public, intens dezbătute în perioada timpurie a Republicii de la Weimar. Deși acest lucru pare surprinzător, sau chiar puțin probabil, la prima vedere, aceste evenimente au devenit extrem de relevante pentru Germania acelei perioade prin reinterpretarea lor în cheie specific germană și prin redimensionarea lor conform contextului german. Acest articol este o contribuție în domeniul istoriei încrucișate (entangled history) și al istoriei mass media. Textul propune un nou mod de interpretare a istoriei relațiilor și influențelor internaționale, abordând această problemă prin prisma dezbaterilor publice, a relatărilor din presă și a discursului politic. 